\title{
The role of amino acid oxidation in causing 'specific dynamic action' in man
}

\author{
By J. S. GARROW AND SUSAN F. HAWES \\ Medical Research Council, Clinical Research Centre, \\ Watford Road, Harrow \\ (Received 26 May 1971 - Accepted $29 \%$ fuly 1971)
}

\begin{abstract}
I. The increase in metabolic rate which occurs after ingestion of protein (the so-called 'specific dynamic action') has been attributed to the energy requirements for urea synthesis and amino acid degradation.

2. We have tested, in normal adult subjects, the effect of meals which increase or decrease the rate of urea production, and our results do not substantiate this hypothesis.

3. The difficulties of accurate measurement of resting metabolic rate are discussed.

4. The term 'specific dynamic action' is inappropriate since the effect is not specific. We believe that it may prove to be a reflection of protein synthesis rather than of protein catabolism.
\end{abstract}

A concise and dogmatic statement of the nature of 'specific dynamic action' is given by Ganong (1969): 'An amount of protein sufficient to provide roo kcal increases the metabolic rate a total of $30 \mathrm{kcal}$; a similar amount of carbohydrate increases it $6 \mathrm{kcal}$; a similar amount of fat, 4 kcal.' Davidson \& Passmore (1969) are more guarded: if a fasting, resting man is given protein to meet his basal calorie expenditure 'his output of energy may increase up to $30 \%$ whereas with a similar amount of carbohydrate, the increase may be less than 5\%'. An explanation of the protein effect on a biochemical basis is given by Krebs ( 1964 ) who attributes the extra heat production in approximately equal parts to two factors - the 'energy requirements for urea synthesis', and the 'wasting of some of the energy of amino acid degradation' in the formation of ATP.

This explanation, if true, is of great interest to those who try to measure total rates of protein turnover in man. To obtain quantitatively reliable estimates of protein turn-over it is necessary to use a technique of continuous infusion of labelled amino acid until an isotopic steady state is reached (Waterlow, I970). To achieve this takes about $24 \mathrm{~h}$, and it is not possible by this method to measure short bursts of protein synthesis, such as those which may occur after a meal. If the increased oxygen uptake after a meal relates to the oxidation of amino acids as Krebs proposed, or the energy cost of protein synthesis, as proposed by Ashworth ( 1969 ), then the measurement of metabolic rate during a long-term isotope study would provide additional information about fluctuations in the total rate of protein turn-over.

The work described in this paper was designed to find out if there is a correlation between oxygen uptake and urea production after a meal, as there should be according to the explanations of Krebs (r964). 


\section{EXPERIMENTAL}

\section{Subjects and methods}

All subjects were volunteers in apparently good health who understood the nature of the experiments. Their age, sex, weight and height are given in Table $\mathrm{I}$.

For the measurements of metabolic rate the subject's head was enclosed in a clear plastic box with a neck seal of thin plastic sheeting (Fig. I). Room air was drawn

Table I. Age, sex, weight and height of the experimental subjects

$\begin{array}{ccccc}\begin{array}{c}\text { Subject } \\ \text { no. }\end{array} & \text { Sex } & \begin{array}{c}\text { Age } \\ \text { (years) }\end{array} & \begin{array}{c}\text { Wt } \\ (\mathrm{kg})\end{array} & \begin{array}{c}\text { Height } \\ (\mathrm{cm})\end{array} \\ \mathrm{I} & \mathrm{M} & 4 \mathrm{r} & 76 & 183 \\ 2 & \mathrm{~F} & \mathbf{2 2} & 68 & 163 \\ 3 & \mathrm{M} & \mathbf{2 3} & 68 & \mathbf{1 7 2} \\ 4 & \mathrm{~F} & \mathbf{2 4} & 70 & 168 \\ 5 & \mathrm{M} & \mathbf{2 2} & 73 & \mathrm{182}\end{array}$

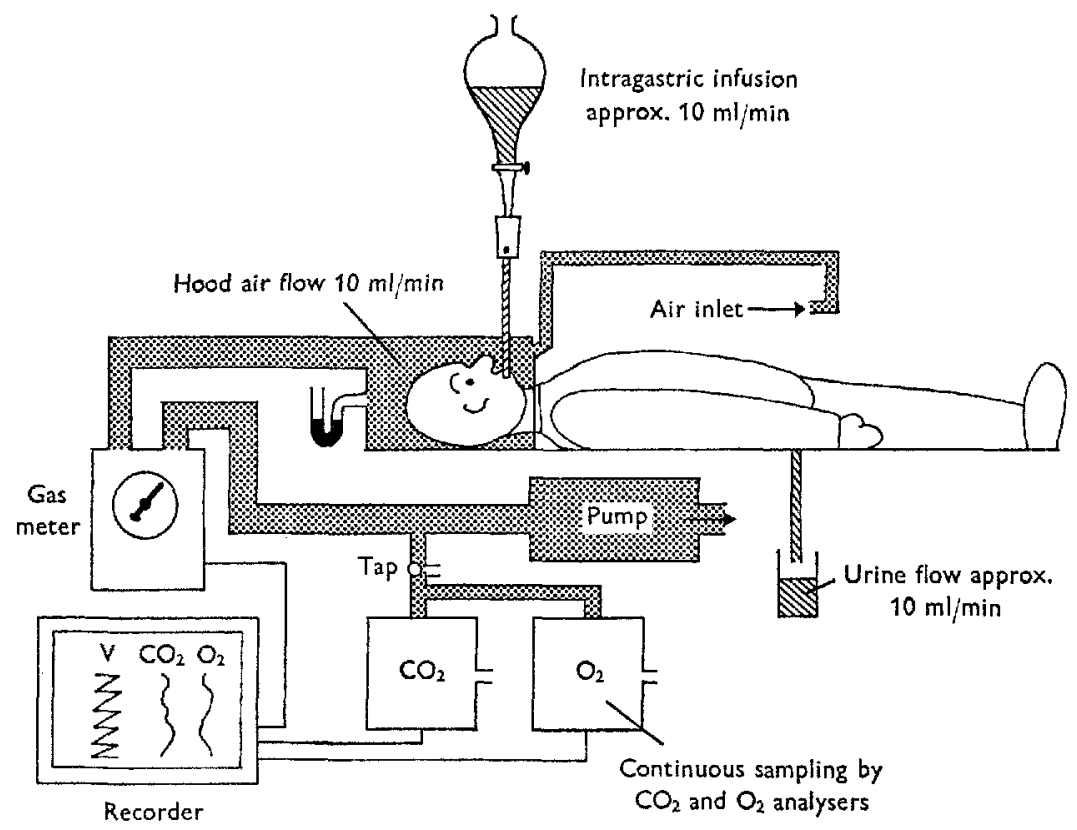

Fig. I. Diagrammatic representation of the apparatus used for continuous monitoring of metabolic rate in resting subjects.

through the box at a rate of ro-I $5 \mathrm{l} / \mathrm{min}$; the exact rate was measured on a dry gas meter (Parkinson Cowan, Stretford, Manchester) and the composition of the gas leaving the hood was analysed for oxygen on a paramagnetic analyser (Servomex, Crowborough, Sussex) and for carbon dioxide by an infrared analyser (Elliott Medical Automation, Rochester, Kent). The output of the analysers, and a signal indicating each revolution of the gas meter, were registered on a multi-channel pen recorder. 
Three experiments were made. Expt A consisted of five studies all on the same subject (no. I) and differed only in the food administered. Throughout a $7 \mathrm{~h}$ period, from 09.00 to 16.00 hours, the subject was at rest in a quiet, warm room, and an intragastric infusion of water containing $30 \mathrm{mmol}$ sodium chloride $/ \mathrm{l}$ was given at the rate of Io $\mathrm{ml} / \mathrm{min}$. Urine was collected every $15 \mathrm{~min}$. Oxygen consumption and carbon dioxide production were measured continuously, but for purposes of calculation the results are expressed as average values for $15 \mathrm{~min}$ periods for the ist hour, and thereafter for $45 \mathrm{~min}$ periods. 'The analyses for carbon dioxide were used primarily to check on the other gas measurements and to detect artifacts due to hyperventilation, and no further calculations were made on these values.

In each study the test meal was substituted for the saline solution in the intragastric infusion between 09.30 and 10.00 hours, without in any way disturbing the subject, who was usually unable to detect the change from saline to food. In run no. I ("nothing') no food was given, but the intragastric saline infusion was continued throughout. In run no. 2, 240 g Complan (Glaxo, Greenford, Middx) were given dissolved in $600 \mathrm{ml}$ water: this provided $4.52 \mathrm{MJ}$ (I080 kcal), $70 \mathrm{~g}$ protein, $40 \mathrm{~g}$ fat and $100 \mathrm{~g}$ carbohydrate. Run no. 3 was a repetition of no. 2 except that the calorie components of Complan were omitted, and only the electrolytes were given. Run no. 4 was similar to no. 2 in total calories and electrolytes, but sucrose was the sole source of energy. In the final run of this experiment ('gelatin') the total protein, calories and electrolytes were the same as in run no. 2, but gelatin was the sole source of protein. Thus, whereas in run no. 2 the protein was of high biological value, and hence suitable for tissue synthesis, in run no. 5 the tryptophan deficiency of gelatin ensured that it was not available for tissue synthesis, but could only be oxidized with the consequent formation of urea.

Expt B was also done on subject no. 1. Measurements of respiratory gases were made continuously from 09.00 to 13.00 hours, and the test meal was given between 09.45 and 10.00 hours. Urine was collected, and blood samples were taken from an indwelling intravenous needle, half-hourly. Run no. I, in which water was given as the test meal, was included to test if the blood sampling procedures would affect the metabolic rate irrespective of any effect due to food. In run no. 2 the test meal consisted of $162.5 \mathrm{~g}$ gelatin dissolved in $1300 \mathrm{ml}$ water. The composition of this meal was determined by the solubility of gelatin in water and the volume of feed which could be tolerated as a rapid intragastric infusion. Subsequent feeds in this series provided the same total energy, namely $2 \cdot 7^{2} \mathrm{MJ}\left(6_{5} \mathrm{o} \mathrm{kcal}\right)$. In run no. 3 sucrose was substituted for gelatin. In run no. 4 milk was substituted isocalorically for some of the sugar so that $7 \%$ of the calories were provided by milk protein. This was done to test the theory that minimum thermic effect occurs when the protein : calorie ratio of the meal is most accurately balanced according to the requirements of the recipient (Hamilton, 1939). A diet of $7 \%$ protein calories may not be ideally balanced for an adult man, but it must be better balanced than $100 \%$ of gelatin, sugar or fat. Run no. 5 used a pure fat meal to see if the thermic effect would be the same for the same energy content of meal regardless of whether the source was protein, carbohydrate or fat. 
In Expt $\mathrm{C}$ the observations were simplified: the purpose of this series was to discover whether the lack of correlation between 'specific dynamic action' and urea formation was peculiar to subject $\mathbf{I}$, or whether other subjects would give similar results. No blood samples were taken, and urine was collected at the beginning and end of the experiments; otherwise the procedures were as in Expt B. Five subjects were tested, and each was given one meal of gelatin and one of sucrose.

\section{Chemical analyses}

Blood glucose was measured by a modification of the method of Trinder (I969), $\alpha$-amino nitrogen by the method of Yemm \& Cocking (1955) and urea by the diacetyl monoxime method (Wootton, 1964).

The total $\mathrm{N}$ content of urine was measured by a micro-Kjeldahl technique and nonurea $\mathrm{N}$ by difference. Urine sodium, potassium and creatinine were measured by standard methods (Wootton, 1964). In Expts A and B the assumption was made that creatinine excretion was constant throughout the study, in order to correct for incomplete bladder emptying at the end of each collection period. The amount of urine solutes attributed to each collection period has therefore been corrected by a factor which gives constant creatinine excretion in each period.

\section{RESULTS}

\section{Expt $A$}

The results of this experiment are summarized in Table 2. The specific dynamic action of the feed was calculated by taking as a base-line the oxygen consumption during the first $0.75 \mathrm{~h}$ of the experiment, and expressing the oxygen consumption during the subsequent $6 \cdot 25 \mathrm{~h}$ as a percentage increase over the base-line. In run A. I there was a negative effect of $0.9 \%$, and the same result was obtained in the 'electrolyte' run: both these results are, within the limits of experimental error, equivalent to a zero response.

In all the runs in which food was supplied there was a positive response, which amounted to increases in oxygen consumption of $8.8 \%, 19.0 \%$ and $16.3 \%$ for the Complan, sucrose and gelatin meals respectively. However, the response in urea excretion was quite unlike that of oxygen consumption: with sucrose the latter rose to a peak $2 \mathrm{~h}$ after the feed, at which time the excretion rate of urea fell below the baseline values. On the other hand, in the gelatin run $5 \mathrm{~h}$ after the feed the oxygen consumption had virtually returned to base-line but urea excretion continued $40 \%$ above base-line values.

The conclusion from this experiment, therefore, is that there is no connexion between 'specific dynamic action' and urea formation in either the magnitude or timing of this effect. However, this conclusion involves three assumptions: first, that the results are reproducible; second, that urea excretion is a valid measure of urea formation over the period of measurement; and third, that the feeds are all being absorbed at approximately the same rate, and consequently are available for metabolism over a similar period of time. Expt B was designed to test these assumptions. 


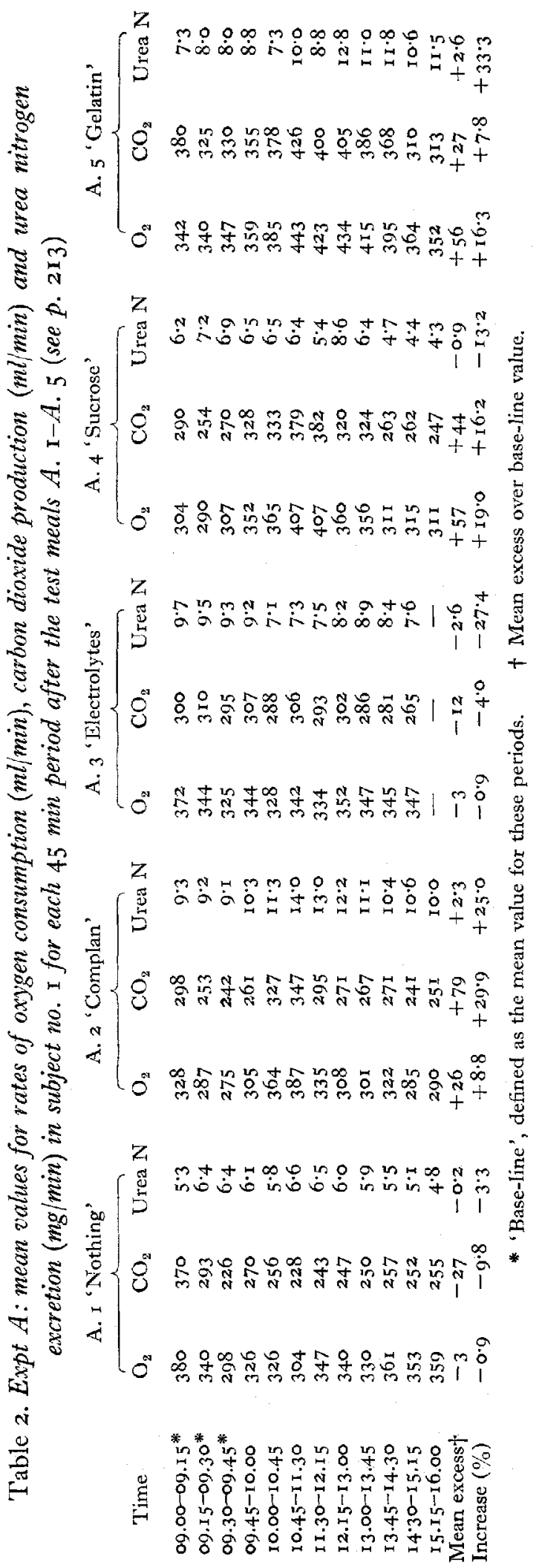




\section{Expt $B$}

The results are shown in Table 3 . In run no. I the average oxygen uptake for $3.5 \mathrm{~h}$ after the feed was increased by $4 \cdot 7 \%$ over the base-line, although only water was given. This is probably a fair estimate of the metabolic stimulation produced by halfhourly blood sampling. On the continuous oxygen recording these sampling periods were clearly marked by transient increases in oxygen uptake. A similar calculation for gelatin and sugar gives increases of 18.8 and $6.6 \%$ respectively, despite the fact that the absolute oxygen uptake after gelatin (average $349 \mathrm{ml} / \mathrm{min}$ ) was lower than after sugar $(370 \mathrm{ml} / \mathrm{min})$. This is because the base-line at the beginning of the gelatin run was very low $(294 \mathrm{ml} / \mathrm{min}$ ) and before sugar it was high $(347 \mathrm{ml} / \mathrm{min})$ : no explanation for this effect can be given. In the run with $7 \%$ milk-protein-with-sugar there was an increase of $14.6 \%$ over a base-line of $315 \mathrm{ml} / \mathrm{min}$, and in the run with fat an increase of only $3.2 \%$ over a base-line of $312 \mathrm{ml} / \mathrm{min}$.

Table 3. Expt B: oxygen consumption, mean rates of excretion of nitrogen, potassium and glucose, and mean blood concentrations of urea, amino nitrogen and glucose in subject no. $\mathrm{I}$ during $3 \cdot 5$ following the test meals

\begin{tabular}{|c|c|c|c|c|c|}
\hline Variable & $\begin{array}{c}\text { B. I } \\
\text { 'water' }\end{array}$ & $\begin{array}{c}\text { B. } 2 \\
\text { 'gelatin' }\end{array}$ & $\begin{array}{c}\text { B. } 3 \\
\text { 'sugar' }\end{array}$ & $\begin{array}{c}\text { B. } 4 \\
\text { ‘ } 7 \% \text { milk } \\
\text { and sugar' }\end{array}$ & $\begin{array}{l}\text { B. } 5 \\
\text { 'fat' }\end{array}$ \\
\hline \multicolumn{6}{|l|}{$\mathrm{O}_{2}$ consumption $(\mathrm{ml} / \mathrm{min})$} \\
\hline Base-line & 306 & 294 & 347 & 315 & 312 \\
\hline $0-3.5 \mathrm{~h}$ after meal & 315 & 349 & 370 & $3^{6 \pi}$ & $35 \mathrm{I}$ \\
\hline Increase $(\%)$ & 47 & $18 \cdot 8$ & $6 \cdot 6$ & $14 \cdot 6$ & $12 \cdot 5$ \\
\hline \multicolumn{6}{|l|}{ Urinary excretion } \\
\hline Total N (mg/min) & $8 \cdot 9$ & 14.9 & II I I & $8 \cdot 3$ & $12 \cdot 1$ \\
\hline Urea $\mathrm{N}$ (mg/min) & 8.8 & $12 \cdot 6$ & ro. I & $7 \cdot 2$ & $\tau \cdot 5$ \\
\hline $\mathrm{K}(\mathrm{mmol} / \mathrm{min})$ & 0.06 & 0.13 & 0.05 & 0.05 & 0.08 \\
\hline Glucose $(\mathrm{mmol} / \mathrm{min})$ & 0 & $\circ$ & $37 \cdot 3$ & $18 \cdot 2$ & o \\
\hline \multicolumn{6}{|l|}{ Blood concentration } \\
\hline Urea $(\mathrm{mmol} / \mathrm{l})$ & $3 \cdot 5$ & $5 \cdot 2$ & $3 \cdot 5$ & $2 \cdot 9$ & $3 \cdot 2$ \\
\hline$\alpha$-amino $\mathrm{N}(\mathrm{mmol} / \mathrm{l})$ & $3 \cdot 2$ & $8 \cdot \pi$ & $2 \cdot 7$ & $3 \cdot r$ & $3 \cdot 0$ \\
\hline Glucose $(\mathrm{mmol} / \mathrm{l})$ & $4 \cdot 2$ & $4 \cdot 4$ & 47 & 59 & $3 \cdot 9$ \\
\hline
\end{tabular}

The other results shown in Table 3 suggest that the assumptions stated above can justifiably be made. In this series, as in the previous one, there was no connexion between 'specific dynamic action' and urea formation, and the time-course of blood urea changes was similar to that of urinary urea changes; there is therefore no reason to doubt that increased excretion of urea reflects increased urea formation and hence increased deamination of amino acids. The third assumption was also upheld: in the blood sample taken $0.5 \mathrm{~h}$ after the meal in run no. 2 the concentration of $\alpha$-amino $\mathrm{N}$ increased to $4.9 \mathrm{mmol} / 1$ from a base-line value of $3.0 \mathrm{mmol} / \mathrm{l}$, and similarly in runs nos. 3 and 4 blood glucose concentration $0.5 \mathrm{~h}$ after the meal increased to 6.2 and $8.6 \mathrm{mmol} / \mathrm{l}$ from base-line values of 3.8 and $5.5 \mathrm{mmol} / \mathrm{l}$ respectively. In run no. 5 blood lipids were not measured, but the sample $0.5 \mathrm{~h}$ after the meal was visibly lipaemic, so absorption from the gut was rapid for all the foods tested. 


\section{Expt $C$}

The effect of the test meals of Expt $\mathrm{C}$ on oxygen uptake and urea excretion is shown in Fig. 2. There was considerable individual variation in response, but in all subjects the oxygen consumption following the sugar load reached a maximum within $\mathrm{r} h$ of the end of the meal, and by $3.5 \mathrm{~h}$ it was back to base-line values or less. Following the gelatin meal, however, there was no clear peak in oxygen uptake, and the effect was not complete by the end of the $3.5 \mathrm{~h}$ study period.

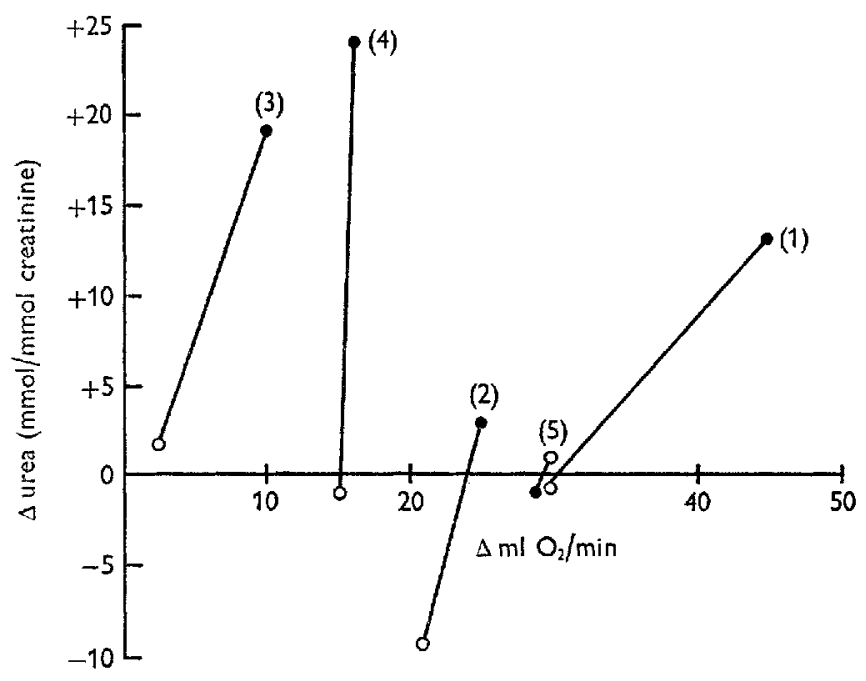

Fig. 2. Series $\mathrm{C}$ : change from before-feeding values for the rates of urea excretion and oxygen uptake in normal subjects nos. ( $\mathrm{I}$ )-(5) after a meal of $80 \mathrm{~g}$ gelatin in $400 \mathrm{ml}$ water (closed circles) or $80 \mathrm{~g}$ sugar in $400 \mathrm{ml}$ water (open circles). The before-feeding values are mean rates for $30 \mathrm{~min}$ at rest, and the after-feeding values mean rates for the $3.5 \mathrm{~h}$ after the test meal, which was given by intragastric tube, without disturbing the subject.

Four of the five subjects excreted more urea per mmol creatinine in the $3.5 \mathrm{~h}$ after the gelatin than they had done before the meal. Following the sugar meal one subject excreted more urea, one less, and three showed virtually no change in urea excretion. On Krebs's (1964) explanation of specific dynamic action, the change in oxygen uptake should correlate with the change in urea excretion, but this was obviously not so. Subject 2, who produced less urea after the sugar meal, nevertheless had an increase in oxygen uptake almost as great as that after the gelatin meal. The three subjects $(1,4$ and 5$)$ with unchanged urea excretion after sugar all showed an increase in oxygen uptake, and this extra oxygen can hardly have been used for 'the energy requirements of urea synthesis' unless this urea had been taken up by bacteria in the gut and recycled back into the metabolic amino acid pool: certainly it was not excreted. Subject 3 provides results most in accord with the Krebs explanation, since the meal followed by the greater urea excretion was also associated with the greater oxygen uptake. However, of all the subjects, he produced the smallest specific dynamic 
action, and it is uncertain if an increase of only $10 \mathrm{ml}$ oxygen $/ \mathrm{min}$ is great enough to permit accurate comparison of the effect of the two meals. Subject $x$ showed a larger effect after the gelatin meal than after an isocaloric meal of sugar, but this cannot be advanced as evidence in favour of Krebs's hypothesis because in this experiment, as in the previous series, he had a large 'specific dynamic action' in response to a sugar meal, therefore not associated with amino acid oxidation or urea synthesis.

\section{DISCUSSION}

The results described above demonstrate two points. One is that it is technically very difficult to quantitate specific dynamic action in man, and the other is that we have completely failed to find evidence to support the contention that this action is attributable 'in approximately equal share... [to] . . the energy requirements for urea synthesis [and] the wasting of some of the energy of amino acid degradation' (Krebs, Ig64).

The technical problems of accurate measurement have nothing to do with the gas analysis: with modern instruments this can be done with great ease and accuracy. The problem is that the metabolic effect of a sugar meal may be over in $3 \mathrm{~h}$, but after a protein meal it may persist for up to 16 h (Glickman, Mitchell, Lambert \& Keeton, 1948). The increase in oxygen consumption following a meal of average size is about 10\% above base-line, and this basal metabolism, even under carefully controlled conditions, shows rhythmical variations of some $20 \%$ over a $24 \mathrm{~h}$ period in both man and animals (Aschoff \& Pohl, r970). Nor is basal metabolism entirely constant from day to day. Carpenter \& Fox (1929-30) tried to measure the specific dynamic action in man following the ingestion of $5 \mathrm{~g}$ laevulose, a work of 'extraordinary exactitude' as Lusk (1930-1) approvingly commented. Considering that in six replicate measurements on different days the basal carbohydrate metabolized varied from 3.1 to $8.5 \mathrm{~g} / \mathrm{h}$, it is indeed remarkable that they were able to conclude that the ingestion of $5 \mathrm{~g}$ of carbohydrate caused an increase in metabolic rate of $0.5 \mathrm{cal}$ in $\mathrm{I} \mathrm{h}$.

To some extent the variations in basal metabolism noted by earlier workers are due to factors such as the discomfort of a closely fitting face mask or inevitable disturbance in the process of taking gas samples. We tried to minimize these artifacts by providing a constant and comfortable environment in the ventilated hood, and by the use of automatic recording equipment, but the variations in basal metabolism were still considerable from day to day.

Bearing in mind the limitations of accuracy discussed above, the lack of support for the Krebs hypothesis is nevertheless quite striking. We found a similar increase in metabolic rate for a given energy content of test meal, regardless of the nutrient content, and cannot agree with the statement quoted from Ganong (1969) at the beginning of this paper. The results on which that statement were made were essentially those of Lusk (r930-I), who, like Rubner (1902), measured the metabolic rate of dogs given meat, sugar or lard. Not surprisingly, in view of the carnivorous nature of dogs, the energy expenditure was higher on days when they were given meat than when they were given sugar or lard, but the original publication gives no measurement of the 
physical activity of the dogs on the different diets. It is therefore open to doubt whether anyone has shown in vivo a greater effect on resting metabolic rate of protein rather than carbohydrate or fat.

Krebs statement not only affirms the 'specific' action of protein (as opposed to carbohydrate or fat) but also offers an explanation. One must accept his account of the thermodynamics of the metabolic reactions involved, and the agreement between the calculated specific dynamic action of proteins and that reported experimentally is very striking. However, our results may be interpreted as showing that, in normal human adults, after a non-protein meal (i.e. when amino acid oxidation and urea formation are not involved) there is a quantitatively similar 'non-specific' dynamic action. The biochemistry of this effect is not clear, but the suggestion that it is to do with the energy cost of protein synthesis (Ashworth, 1969) is at least compatible with our results.

It could be argued that Krebs might be correct in his account of the dynamic action after a carbohydrate meal also: it is known that urea may be recycled back into protein to some extent. The explanation would then be that the dynamic action after a sugar meal was, as before, due to the energy requirements for urea synthesis, but that our failure to find the extra urea was due to recycling back into protein, such as might occur under conditions of protein-free feeding. This explanation seems inherently improbable and is, in any event, the two explanations combined into one: it postulates both increased urea formation and increased protein synthesis, so it would not be possible to attribute the extra metabolic work to one or the other exclusively.

We conclude, therefore, that specific dynamic action in normal adult man is not a response specific to a protein meal, nor is it primarily or necessarily a reflection of amino acid oxidation or urea formation.

We are most grateful to W. Martin, R. Hutchings and A. Coggins for their cooperation as experimental subjects, and to M. Snook and his colleagues in the Department of Clinical Chemistry for help with the chemical analyses.

\section{REFERENCES}

Aschoff, J. \& Pohl, H. (1970). Fedn Proc. Fedn Am. Socs exp. Biol. 29, 1541.

Ashworth, A. (1969). Nature, Lond. 223, 407.

Carpenter, T. M. \& Fox, E. L. (1929-30). F. Nutr. 2, 389.

Davidson, S. \& Passmore, R. (1969). Human Nutrition and Dietetics 4 th ed. Edinburgh: E. \& S. Livingstone.

Ganong, W. F. (I 969). Reviero of Medical Physiology 4th ed. Los Altos: Lange Medical Publications.

Glickman, N., Mitchell, H. H., Lambert, E. H. \& Keeton, R. W. (I948). F. Nutr. 36, 40.

Hamilton, T. S. (1939). F. Nutr. 17, 583 .

Krebs, H. A. (1964). In Mammalian Protein Metabolism Vol. I, p. 125 [H. N. Munro and J. B. Allison, editors]. New York: Academic Press.

Lusk, G. (1930-1). F. Nutr. 3,519.

Rubner, M. (1902). Die Gesetze des Energieverbrauchs bei der Ernährung. Leipzig and Vienna: Franz Dauticke.

Trinder, P. (1969). F. clin. Path. 22, 246.

Waterlow, J. C. (1970). Nutr. Rev. 28, I 15.

Wootton, I. D. P. (1964). Micro-analysis in Medical Biochemistry $4^{\text {th }}$ ed. London: J. \& A. Churchill.

Yemm, E. W. \& Cocking, E. C. (1955). Analyst, Lond. 80, 209. 